\title{
A Perspective on Stratigraphic, Vertically-Upward "Displacements or Dislocations" of Conodont-Elements: An Example From the Upper Devonian, Pre-Lithified, Black Shales of the Chattanooga Shale Formation In Tennessee, USA
}

\author{
Michael Iannicelli \\ Correspondence: Michael Iannicelli, Brooklyn College (C.U.N.Y.), Brooklyn N.Y.; 710921 Ave. Brooklyn, N.Y. \\ 11204, USA. E-mail: michiann@optonline.net
}

Received: April 9, 2019

doi:10.5539/esr.v8n2p35

\author{
Accepted: July 23, 2019 \\ Online Published: July 31, 2019 \\ URL: https://doi.org/10.5539/esr.v8n2p35
}

\begin{abstract}
Stratigraphic "displacements or dislocations" are coarse clasts and / or objects (such as unaltered remains or conodont-elements) slowly mobilizing or migrating vertically upward through a fine-grained matrix by a cryogenetic process known as "upfreezing" due to freezing temperatures. The process was originally established by periglaciologists and cold-climate geomorphologists who applied it only to unconsolidated, sedimentary deposits. In this study, the process is applied to the marine, pre-lithified, black shales of the Upper Devonian, Chattanooga Shale Formation, specifically in Tennessee, USA. The importance of this recognition is to alert paleontologists and stratigraphers about the strong possibility of inaccurate age-determinations made concerning coarse objects such as a conodont-element (denticles) (but not fossilized molds) because of their fossilized presence in age-determined, stratigraphic, rock levels when the apatite-composed denticles may have instead been initially deposited at a lower stratigraphic level during pre-lithification of the fine-grained, host-rock (shale) before the paleo-upfreezing process mobilized the denticles upwards. Many lines of evidences are given in this study towards apparent, predominant, freezing temperatures in the pre-existing, Chattanooga Sea of the Appalachian Basin, including particular, supposed, bioturbated, pre-lithified, organic black shale that is reinterpreted here as cryoturbated, pre-lithified, organic, black shale.
\end{abstract}

Keywords: upfreezing, Upper Devonian Chattanooga Shale Formation, pre-lithified black shale, conodont-elements, Tennessee, USA

\section{Introduction}

The Devonian, marine, pre-lithified, shales of the Chattanooga Shale Formation in Tennessee, USA were most likely subjected to at least seasonal freezing conditions which may have stratigraphically, vertically shifted coarse clasts and / or objects upward such as conodont-elements (denticles) within a predominantly, fine-grained matrix under saturated conditions, by a slow mobilization, cryogenic process known as "upfreezing" (Godzik \& French 2004, p. 362; French 2007, p. 138). This ultimately resulted in inversional positioning during paleo-cold climates, so that coarse clasts and objects ultimately overlaid the whole mass of fine sediment. Pre-lithified, black shales are the focus here, while paleo-seafloor conditions and related paleo-temperatures will be elaborated upon later in the study. An exemplar is whenever a conodont-element is found in a black shale, we may then suspect that it most likely upfreezed originally from a lower level of the stratigraphic column at where a light-colored shale is located. This surmise is ascertained because a pre-lithified, black shale only represents a non-living paleoenvironment while a pre-lithified, light-colored shale is regarded as a feasible, living paleoenvironment. That corresponds to a preclusion of primitive macroorganisms in the former paleoenvironment while the latter paleoenvironment would have sustained primitive macroorganisms. A detailed analysis of this is given later in the study.

Figure 1 depicts the upfreezing process within an unconsolidated mass of clasts with different sizes which was subjected to simple, cold-temperature air. Groundwater or pore water within the sediment is needed for the upfreezing process to take effect (Washburn, 1969; Godzik and French, 2004). It should be noted here that upfreezed objects such as conodont-elements differ markedly from their enclosing, fine-grained matrix (the shale) because they retained their original composition (apatite), thus, making them "unaltered remains".

The attention that will be spent here on different-colored shales within the Chattanooga Shale Fm. (Fig. 2) is 
mostly concerned with black shale units during the Frasnian and Famennian stages of the Upper Devonian Period. Black shale is defined as very fine-grained, organic carbon-rich, sedimentary rock consisting primarily of clay minerals and organic particles (from planktonic algae and plant debris) while secondarily sometimes consisting of very thin, interlaminated, sheets of quartz silt (of probable wind-born origin) (Conant \& Swanson, 1961, pp. 44 and 55; Schieber, 2003a). Other types of black shales in the Chattanooga Shale Fm. are pyritized, black shales, while another type possesses either a monopoly or just a scattering of phosphatic nodules (Fig. 2). A fourth type is bioturbated (Fig. 2), which is a black shale containing seemingly, fossilized structures of burrows created by marine paleo-organisms, known as trace fossils or ichnofacies. But, a re-examination of the last type is made later in this study which may instead, equate particular, trace fossils to very, similar, morphological-looking structures that were caused by cryoturbation due to freezing paleo-temperatures.

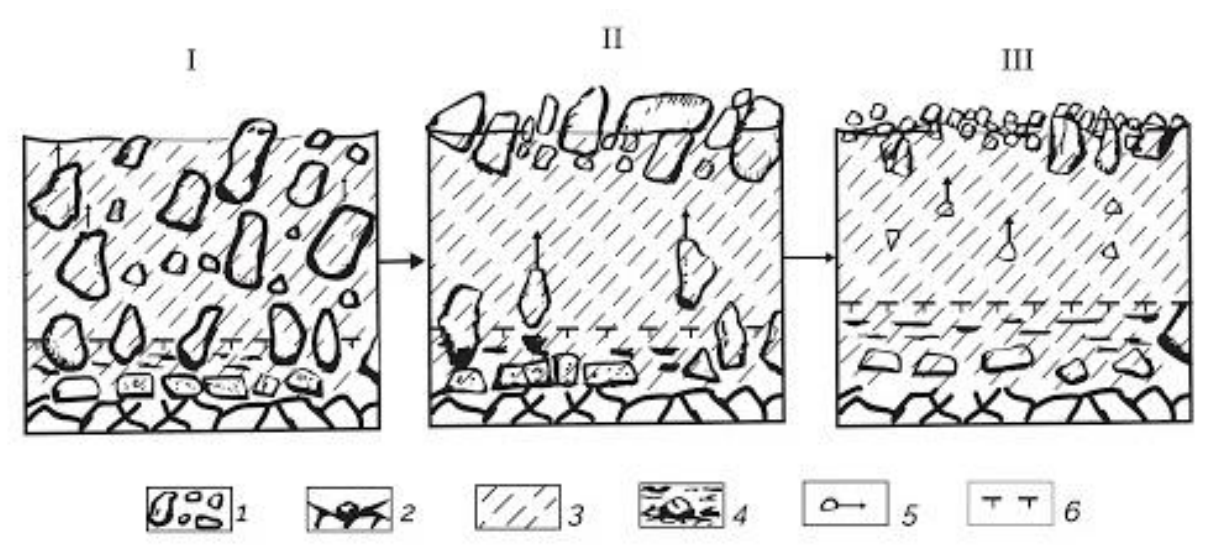

Figure 1. The upfreezing process imposed on an unconsolidated deposit such as eluvium. I: Initial distribution of eluvium consisting of coarse clasts and some fossilized objects intermixed in a fine-grained matrix; II: The scattered, largest clasts /objects migrate fastest to the surface followed afterwards by the smaller clasts / objects arriving to the surface. Of course, any smaller clasts / objects originally near to the surface may arrive to the surface at the same time as the large clasts since there is less fine-grained matrix for them to migrate through. III: Small clasts / objects migrating through the matrix at a slower speed than the large clasts

because of their differential size; and also fragmentation in the bedrock of the regolith is due to common weathering within the subsurface. 1: clasts of cobbles, gravel plus gravel-sized objects. 2: weathered, disjointed rock of the subsurface. 3: finer-grained, loam matrix. 4. ice-inclusions in frozen deposits. 5: directional displacement of detritus by the upfreezing process upon the rock debris and dead-organic remains. 6. boundary of frozen deposit. From Melnikov \& Spesivtsev (2000). Reproduced through the courtesy of Novosibirsk Scientific Publishing Center of the UIGGM (United Institute of Geology, Geophysics and Minerology) 


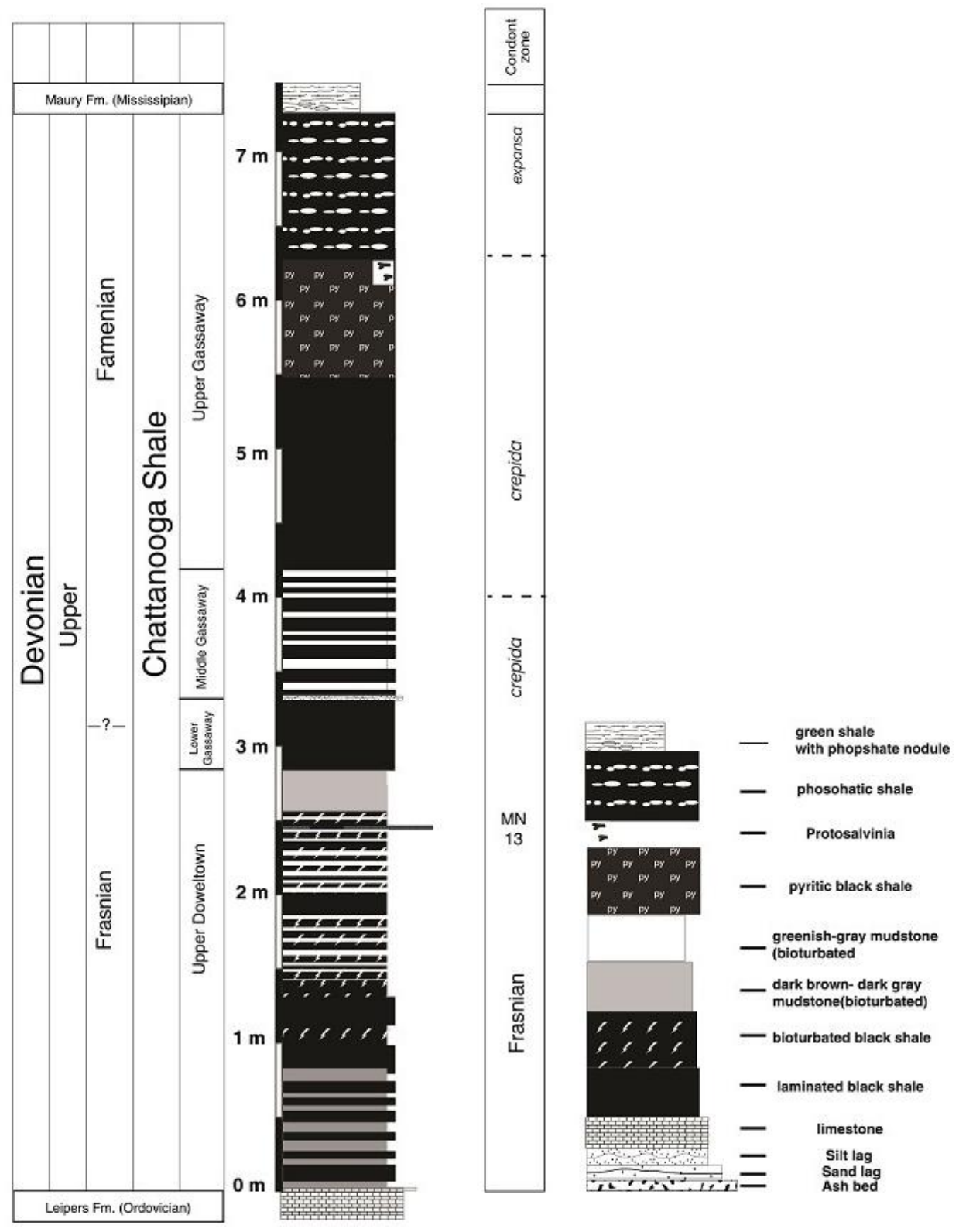

Figure 2. A very detailed, stratigraphic column of the Chattanooga Shale Formation located in Chestnut Mound, TN, USA.This is a very good magnification of the general, stratigraphic column shown in Figure 3. From Li \& Schieber (2015). Reprinted with permission from Elsevier Publishing

\section{Methodology and Materials}

The writer bases the study on existing, scientific data from: primary literature sources namely, peer-reviewed journal papers and monographs. In general, for the sake of whenever anybody attempts to determine an age for specified fossils, the current study presents a critique that should be used promoting accuracy for any age-determinations made on apatite-composed, coarse-size, conodont-elements within a predominantly, fine-grained, matrix such as shale. This is done by first comprehending the literature's application of cold-climate processes (particularly "upfreezing") done upon Recent and Quaternary, unconsolidated deposits which motivates the current study to apply those same geo-dynamic processes to pre-lithified, marine shale deposits of the Upper Devonian Period containing the apatite-composed, conodont-elements (denticles), located in Tennessee, USA. Then estimates can be made whenever paleontologists / stratigraphers attempt to accurately determine an age for conodont-element(s) while broadly concluding that the elements are $\geq$ in age to the surrounding host-rock located at the very same stratigraphic level. The mold 
of the fossil relative to the study's theme is irrelevant here and will be elaborated upon later in this study.

Important material such as a very detailed, stratigraphic column (Fig. 2) was attained in order to see which specific type of pre-lithified, black shale would be feasible for the potentially displaced or dislocated conodont-elements after being subjected to paleo-upfreezing. This will be elaborated upon later in the study when "anoxic" black shale is discussed. The previously-mentioned light-colored shales that underlie the black shale's (Fig. 2) conodont-elements (Fig. 3) may indicate a correlation of where the vertically, displaced conodont-elements originated from. This is because a light-colored shale bed represents a dysoxic, pre-lithifed sediment that occurred together with a dysaerobic paleo-water zone which made it more likely to sustain nektonic, epifaunal and infaunal, macroorganisms. This also will be further elaborated upon later in the study.

Other supporting material is presented in the study such as visual evidence (photographs) of supposed bioturbated, black shale of the Chattanooga Shale Formation while being compared to visual evidence (photos and diagrams) of cryogenic, cryoturbated sediment, to see if a reevaluation of the bioturbated, black shale is warranted. Once the resemblance to one another is deemed as morphologically homologous but structurally distinguishable from one another, then conclusions can be made concerning the paleo-cold climate's effects upon pre-lithified, black shale which will alert paleontologists to make a careful examination at any host-rock preserving fossils such as apatite-composed conodont-element denticles, whenever determining an age for them.

\section{Upfreezing Effects Upon Coarse Grains or Objects Within a Fine-Grained Matrix}

An object such as a conodont-animal's "row of denticles" (also called a "bar-type element") (Prothero, 2013; Iannicelli, 2018) encased in pre-lithified, black shale was most likely subjected to the upfreezing process during a paleo-cold climate, just like it was for all coarse clasts or objects bigger than the fine matrix. Size-wise, the range of a conodont-element measures up to and over $2 \mathrm{~mm}$ in length. The Udden-Wentworth Scale classifies the size of any grain: $\geq 2 \mathrm{~mm}$ as gravel; .0625 to $1.68 \mathrm{~mm}$ as sand; .0039 to $.053 \mathrm{~mm}$ as silt; and .00006 to $.002 \mathrm{~mm}$ as clay. The conodont-animal was a globally ubiquitous, sea fish who possessed denticles (elements) that lived from the Cambrian Period until the Hettangian Stage of the Lower Jurassic Period (Iannicelli, 2017; 2018). The various conodont-element, fossils are composed of apatite (calcium phosphate) that maintained and retained their original composition during fossilization, thus, they were resistant to geochemical alteration since the original, apatite composition was not replaced nor re-mineralized by the surrounding host-sediment during complete lithification. This is in contrast to most other ancient, animals' hard parts during the fossilization process whose dead carcasses are mineralized by the surrounding host-sediment during lithification of that sediment. Even though the conodont-element may leave an impression upon the surrounding host-sediment (known as a "mold"), the apatite-composed, gravel-sized, conodont-element then would have mobilized upwards through a fine-grained, sediment-matrix whenever the cold climate causes the upfreezing of this type fossil. In the meantime, the mold, of course, always keeps its own original, stratigraphic level or position in-situ within the original sediment during complete lithification. This, ultimately means that the mold will never skew an age determination vs. a mobilized conodont-element in which the latter could very well, falsify an age result if it's deemed as a stratigraphic displacement or dislocation in nature. 


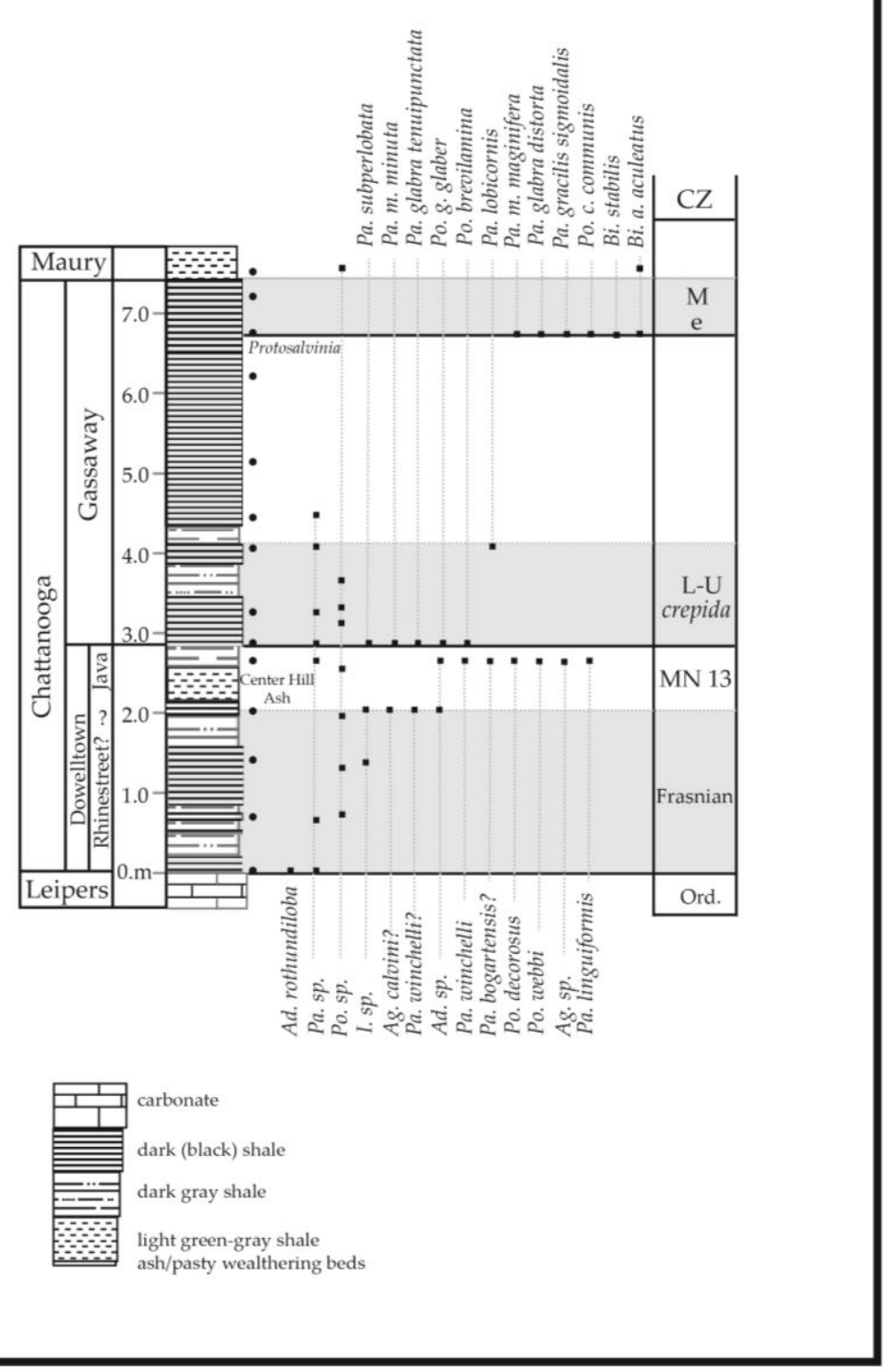

Figure 3. A very general, stratigraphic column of the Chattanooga Shale Formation located in Chestnut Mound, TN, USA that designates various species of the conodont-animal whose elements were found at particular, stratigraphic levels. It is a very broad version of the detailed, stratigraphic column shown in Figure 2.

Abbreviations of the various, conodont species: Ad. = Ancyrodella; Ag. = Ancyrognathus; $\mathrm{Bi} .=$ Bispathodus; $\mathrm{I}=$ Icriodus; Pa. $=$ Palmatolepis; Po. $=$ Polygnathus. $\mathrm{CZ}=$ Conodont Zone $($ which refers to the very first conodont species that initially appeared in the zone). Protosalvinia $=$ fossilized plant of probable terrestrial origin; closed circles with no designated name $=$ conodont-element belonging to an un-named, conodont species. From Over

(2007). Permission to duplicate figure, courtesy of Cambridge University Press

\section{Ramifications Incurred From the Upfreezing Process Upon the Conodont-Elements}

We must consider the ramifications from the upfreezing process upon the conodont-element whenever it was within a pre-lithified, moist, sediment-mass composed of a majority amount of fine clasts smaller in size than the conodont-element which were either silt grains or clay particles. As long as a paleo-cold climate subjects that sediment-mass to freezing temperatures, then the coarse-sized, conodont-element keeps further dislocating or displacing upwards from its original position within the fine-grained, matrix. A reasonable corollary of the above is, a coarse object such as a conodont-element, will always slowly migrate upwards through any colored (light or dark colored), pre-lithified shales until: either freezing temperatures discontinue before lithification of the surrounding-sediment, or if in case, the migrating coarse object makes contact finally with an overlying, coarse 
sediment layer. The latter reason is very sound because coarse clasts and objects can not upfreeze upwards through a matrix containing constituents of either the same-sized grains or bigger grains (Schatzl \& Thompson, 2015).

As mentioned earlier, a consequence of the above to a paleontologist or stratigrapher who is attempting to determine an age for a conodont-element, is the predictable probability of a skewed-age result for the apatite-composed conodont-element that had previously upfreezed before lithification of the surrounding (paleo)host-sediment (shale). One example, is finding many, different conodont-elements strung together along the very same, stratigraphic level within the middle of a very thick, black shale bed, i.e., see Over (2007, fig. 9) (Fig. 3) Here, an anomaly exists because a black shale zone signifies or represents a (paleo)non-living zone (or simply a dead zone) relative to ancient macroorganisms due to a pre-existing, anaerobic paleo-environment that promoted a pre-lithified, black clayey or very fine, silty sediment to develop and accumulate. To account for this type of particular anomaly, investigators such as Barron and Ettensohn (1981) claimed that the upper-most, stratified, paleo-water column must have been sufficiently oxygenated to support nektonic animals simply due to the preservation of conodont-elements and fish scales found within black shales in the Huron and Cleveland members (Ohio Shale Formation) of nearby, eastern Kentucky, USA, since these black shales are time-equivalent to the black shales of the Chattanooga Shale Formation in Tennessee, USA which also envelopes fossilized, conodont-elements (Over, 2007). But an important circumstance that argues against an existence of conodont-animals or even other fish within a supposed, upper-most, stratified, oxic marine layer of the paleo-Chattanooga Sea, is the big thickesses of the black, shale beds themselves in the Chattanooga Shale Fm., such as in Figure 2. Big thicknesses of black shales indicate a very long residence time of a substantial amount of cumulative, black, dead organic, pre-lithified sediment which eventually heightened the paleo-chemocline or paleo-anaerobic marine layer up to virtually the very top of the paleo-water column since Tyson and Pearson (1991, p. 11) report that anoxia constantly expands upward and outward in due time. Thus, the heightened, anaerobic, marine paleo-zone would have suffocated or chased out any nektonic paleo-inhabitants due to the zero level of dissolved oxygen in that paleo-zone while it had to inevitably also deterred distal, nektonic paleo-animals from emigrating into it (Tyson and Pearson, 1990). Distal, nektonic paleo-animals logically and potentially ventured from the paleoenvironment of pre-lithified, light-colored shales that represent at least dysoxic to oxic marine conditions while the preclusion of those nektonic paleo-animals in the black shales starts at the transition of where light-colored shales grade into the black shales. Thus, we may conclude here that paleo-upfreezing of any conodont-element(s) originally buried in the pre-lithified, light-colored shale occurred in order to account for their presence in black shale.

\subsection{Seawater Depth as a Factor in Anoxia Heightening to the Topmost of the Water Column}

Since Schieber (1994) suggested a shallow sea depth for the paleo-Chattanooga Sea during the deposition of black shales while Conant \& Swanson (1961, p. 62) ascertained the water depth there as being shallow at $<30 \mathrm{~m}$ from a considerable distance from the coastline within a shelf setting, then little depth indicates that an oxic, stratified upper layer of the paleo-water column unlikely existed there due to anoxia being heightened up through a relatively thin layer of water $(<30 \mathrm{~m})$. This is further reinforced by Conant \& Swanson's (1961, fig. 13) diagram which places the pre-lithified, black shale within Tennessee only at the edge of the paleo-geographical, structural basin that is again, shallow in depth. The sub-theme of anoxia occupying virtually the whole paleo-water column will be further verified later in section 8 of the study where it corroborates the full-scale anoxia concept by comparing it with a confirmed, full-scale, anoxic, structurally deep, paleo-seawater basin in Canada that contained deposits of pre-lithified black shale (which ultimately lithified to become the Duvernay Formation). There, anoxia progressively rose up through great depths of paleo-seawater which ultimately eliminated oxygen even in the topmost stratified part of it (Sinninghe-Damste \& Shouten, 2006).

\subsection{Other Levels of Marine Anoxia}

A second and a third, relevant, pre-lithified, black shale zone that resulted from the anaerobic water layer were formed immediately just above the paleo-seafloor and below it, respectively. There, we shouldn't expect to find any evidence of paleo-benthos existing just above the paleo-seafloor since investigators such as Diaz \& Rosenberg (2008) simply advocated that whenever a marine, anaerobic condition is reached, then benthic organisms are eradicated. This precludes epifauna such as ancient brachiopods from existing there upon the paleo-seafloor. Conant \& Swanson (1961) reported about some various, Upper Devonian-aged, fossilized, phosphate-composed, brachiopod shells in Tennessee, USA, but they did not mention specifically if whether they were fossilized within either black shales or light-colored shales of the Chattanooga Shale Fm. But the time-equivalent, black shale of the previously-mentioned Cleveland Member (Ohio Shale Fm.) does contain various brachiopods (Barron \& Ettensohn, 1981), which means that the shells can be explained and scrutinized according to the paleo-upfreezing and displacement / dislocation criteria or upfreezing-scheme being used in the current study. Differentially, in the 
case of the unique paleoecology of phosphatic brachiopods named Orbiculodea sp., Schizobolus sp. and Lingulapora sp., authorities such as Barron and Ettensohn (1981) said they were epiplanktonic since they were found fossilized while attached to terrestrially-derived, plant debris and wood logs that floated at the very surface of the paleo-sea, thus, providing themselves with an excellent chance to breathe when escaping an anaerobic paleo-seafloor. The paleo-plant material was generated within the marginal-marine environment which is where larvae attached themselves to the plant-material before drifting far out offshore (Barron and Ettensohn, 1981). The survival of these particular brachiopods at the seawater / atmosphere interface is still compatible with the central thesis of the current study since the inevitable sinking of the plant material (due to added weight consequent to growth of the brachiopods) with their attached brachiopods fell downwards toward the anaerobic paleo-seafloor where they inevitably perished, which then amply accounts for their unique point of origination whenever found in black shale (Barron and Ettensohn, 1981). Finally, the third zone of concern, is the subsurface of the paleo-seafloor containing supposed infauna of trace fossils in pre-lithified, black shales, specifically Chondrites and Planolites which represent ancient bioturbations by extinct, marine worms (i.e., polychaete sp.) that left behind fossilized burrows below the surface of the anoxic, paleo-seafloor of the paleo-Chattanooga Sea within the Appalachian Basin (Schieber, 1994; Schieber, 2003b). But Barron and Ettensohn (1981) and Over (1990, p. 3) said that we should never expect to find paleo-bioturbations in black shale. This is congruent to Tyson and Pearson (1991, fig. 1) virtually not finding any modern, bioturbation-structures that are deeply burrowed into anoxic sediment, while instead, only finding infauna (such as worms, crustaceans, etc.) originating and extending their burrows first entirely through aerobic sediment to ultimately then either only impinge or slightly penetrate surfaces $\sim 1 \mathrm{~cm}$ into underlying, anoxic, black sediment since Figure 4 shows sparse, vertical, tubular conduits connected to oval-shaped burrows at the $\sim 1 \mathrm{~cm}$ level. We may now scrutinize cross-sections of supposed bioturbations such as Schieber (1994, fig. 9) (Fig. 5) and Schieber (2003b, fig. 1 ) (Fig. 6) versus Tyson and Pearson (1991, fig. 1) (Fig. 4) since Figure 5 lacks any vertical, tubular conduits that lead to the oval and elliptical-shaped burrows which contrasts against Figure 4. Also, the contrast is augmented since Figure 6 displays vertical, tubular conduits originating within the black shale part (reflecting an anoxic paleoenviroment within the surface of the paleo-seafloor) which then extend downward through the black shale to ultimately penetrate gray shale. This, of course, is the exact reversal of Tyson and Pearson (1991, fig. 1) (Fig. 4), who illustrated modern-day marine burrows originating and starting from aerobic sediment but then sequentially tunneling downwards to the top of the next layer composed of anoxic sediment, while either only impinging upon or penetrating just $\sim 1 \mathrm{~cm}$ into the anoxic sediment. Thus, all together, this then renders these particular, ancient bioturbations of the pre-lithified, black shale there in the Chattanooga Shale Fm. as very improbable.

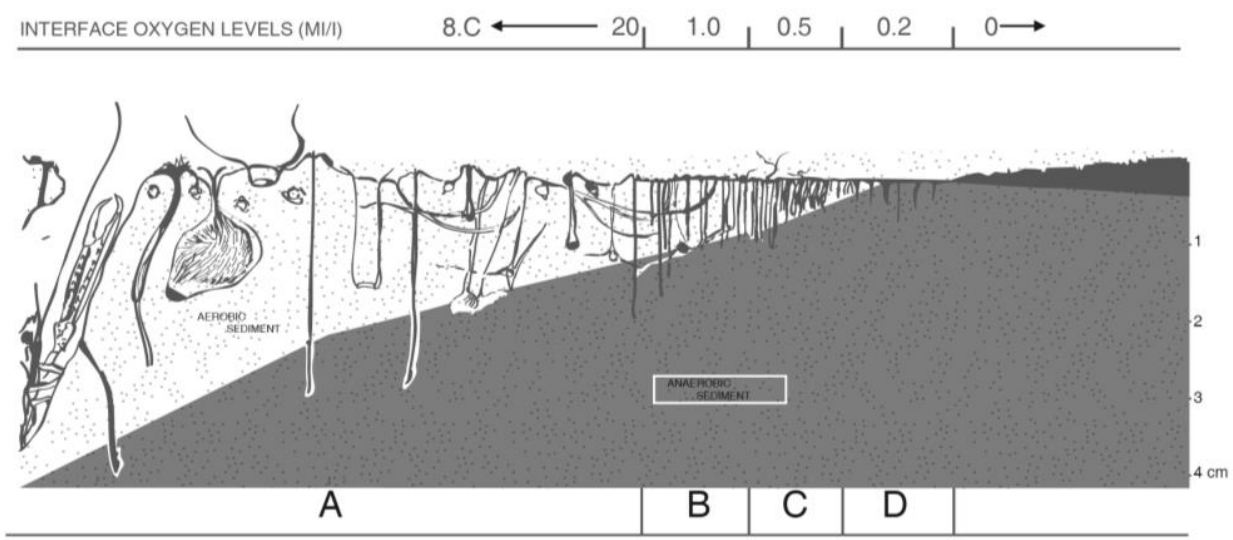

Figure 4. A close-up diagram of a modern-day, bioturbated, unconsolidated substrate of the marine zone. It features a surficial, oxic, thoroughly bioturbated (by infauna such as crustaceans, mollusks, worms, etc.) sediment (speckled, white pattern) which overlies an anoxic sediment layer (speckled, dark gray pattern) that is either only subtly impinged upon or slightly penetrated $(\sim 1 \mathrm{~cm})$ by the overlying infauna of organisms who originated from the oxic, sediment layer. A crustacean occupies the big burrow to the far left side of the reader. From Tyson \&

Pearson (1991). Permission to duplicate figure, courtesy of the Geological Society of America 


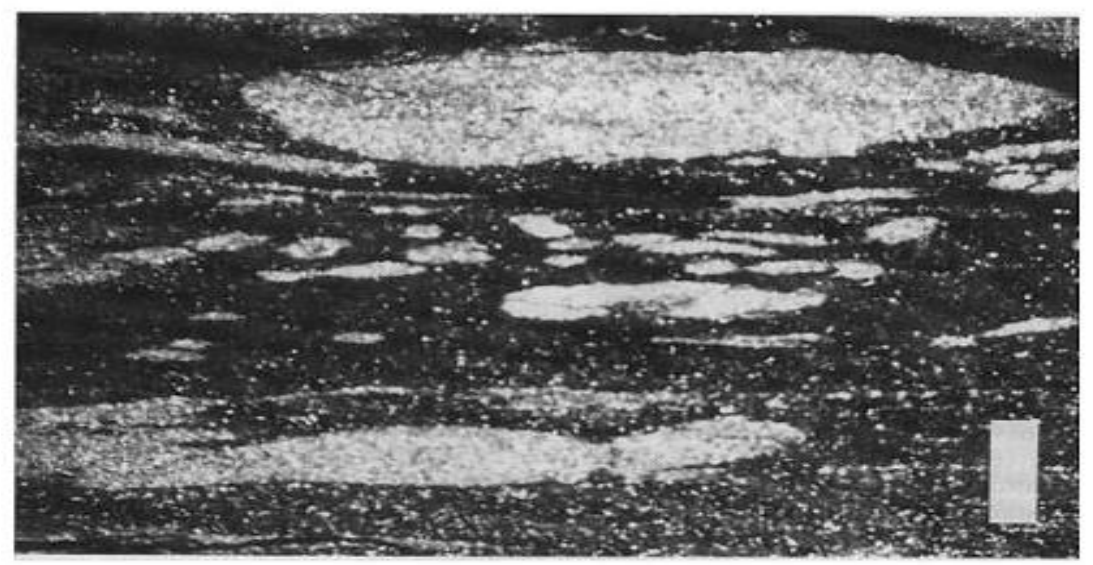

Figure 5. A magnified black \& white photo showing isolated, oval shapes and disjointed, horizontal lineations interpreted by Schieber (1994) as bioturbated, black shale of the Chattanooga Shale Fm. But notice

the absence of vertical, tubular conduits connected to the oval shapes which is contrary to the burrowing-forms in Figure 4. An interpretation of paleo-cryoturbation within the pre-lithified, black shale is deemed here for this particular section of black shale in the current study. Scale bar is $1 \mathrm{~mm}$. From Schieber (1994). Reprinted with permission from Elsevier (Publishing)

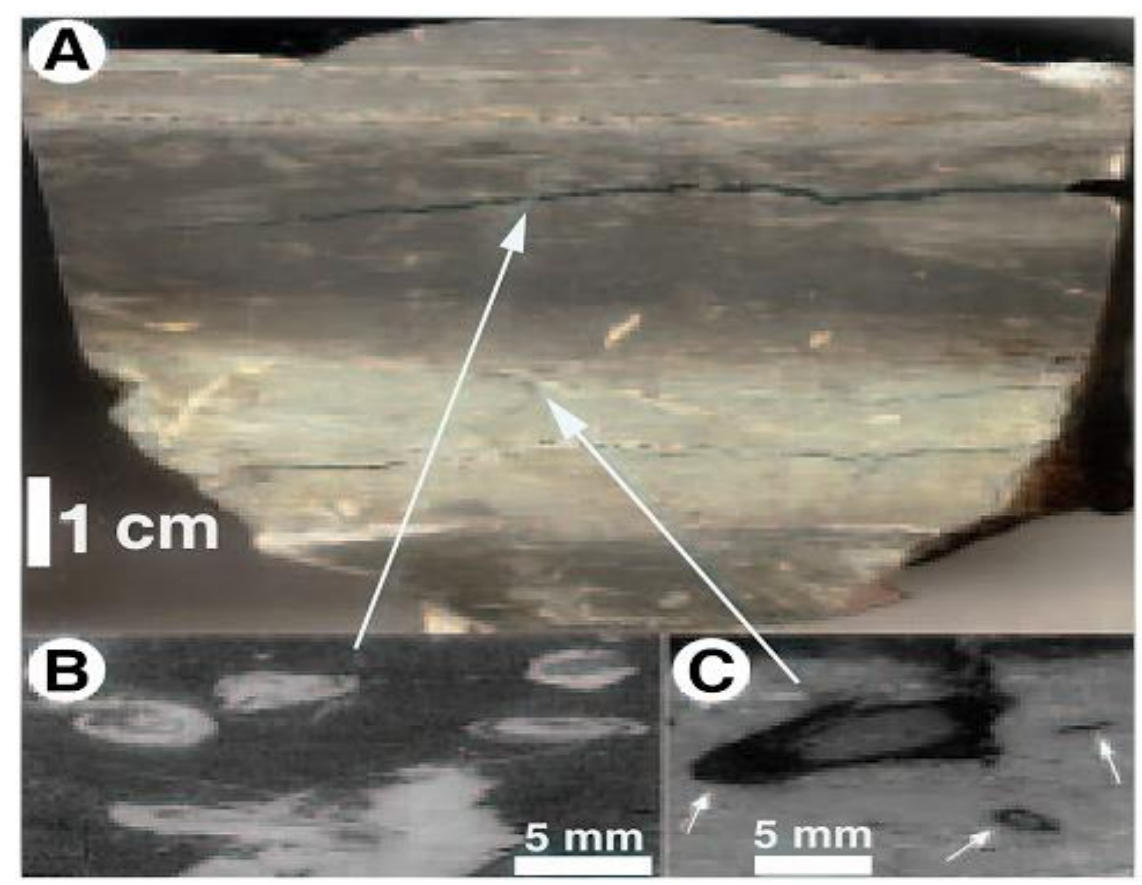

Figure 6. Magnified color and black \& white photos showing a layer of light-colored shale overlying black shale (the middle unit) which is altogether underlain by another light-colored shale (A). As suggested by Schieber (2003b), there is a typical, slight penetration into the black shale by supposed, burrowing organisms originating from within the top layer of the light-colored shale, such as in Figure 4. In (B), the irregular-shaped structure and oval-shaped structures are analogous to cryogenic structures such as the oval and irregular-shaped structures

shown in Figure 8. But a visual anomaly occurs when there are indications of further burrowing into the light-colored, shale of the bottom layer since those burrows were hypothesized by Schieber (2003b) to have originated from the black-shale layer even though the paleo-environmental implication of the black shale is an anoxic sediment zone (C). There is no modern-day analog for this type of bioturbation-pattern which features the preceding in a black shale that is sandwiched by light-colored shales. From Schieber (2003b). Permission to duplicate photo, courtesy of SEPM

A case is made here for a more likely agent in creating the supposed, trace fossils in black shales that represent anoxic, pre-lithified sediment. The study suggests cryoturbation created the structures of the anoxic 
paleo-sediment which was initiated from either paleo-permafrost conditions or at the very least, from paleo-seasonal freezing. When we compare the diagrammatic illustration and photographic illustration of cryoturbated, gravity structures in Figures 7 and 8, respectively versus the photographs of supposed, bioturbations in Figures 5 and 6, the resemblances are similar. Note particularly, Figure 7's ball \& pillow structures that include an isolated, oval-shaped structure without any vertical shaft which resembles a same-shaped structure in Figure 5. Plus, the fact that these ball \& pillow structures in Figure 7 are filled with the same material derived from the overlying, sediment layer, just like Figure 6's structures were filled with the overlying black, paleo-sediment. Also, attention is directed to the lenticular and irregular-shaped structures of supposed, bioturbation structures in Figure 6 resembling the shapes of the cryoturbated structures in the field photo of Figure 8. In addition, the cryogenic, ball

(A)
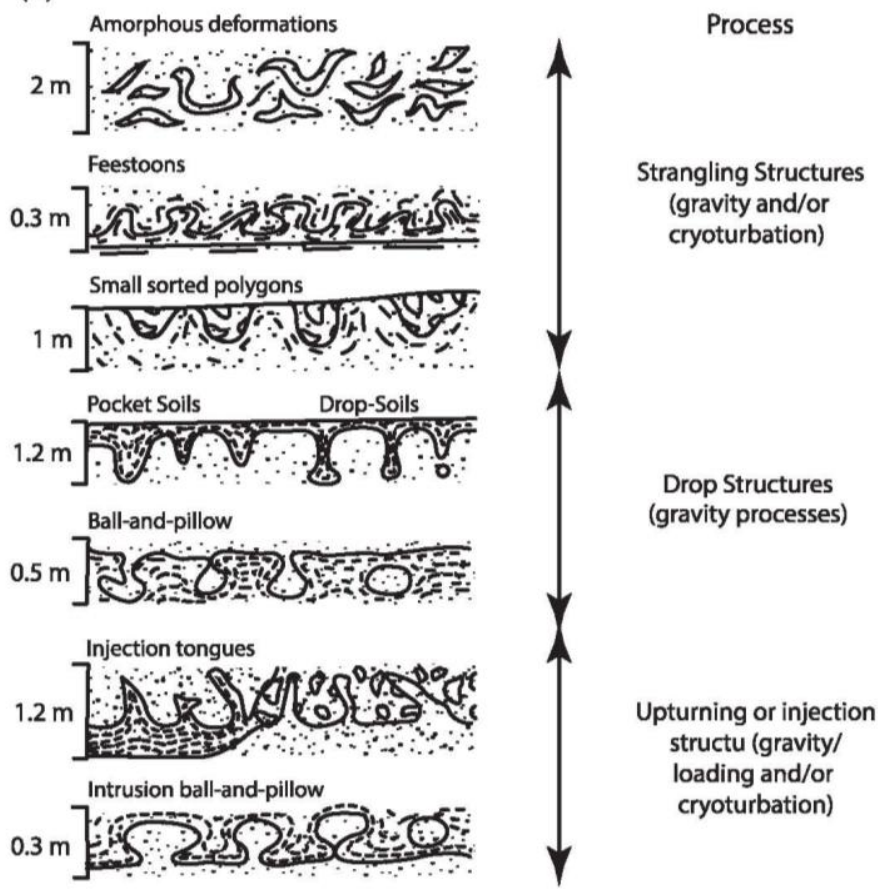

(gravity and/or


Upturning or injection

structu (gravity/

loading and/or

cryoturbation)

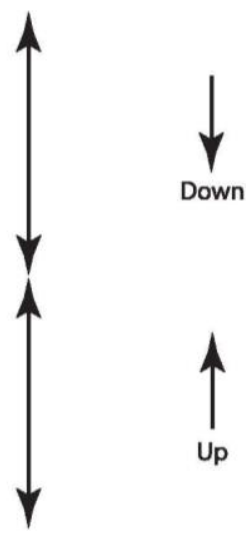

Figure 7. Diagrams of different-shaped patterns of cryoturbation that occurred in Quaternary sediments during either paleo-seasonal freezing of the ground or within the active-layer of permafrost. Of most concern, is the sketch of ball \& pillow shapes that are known as "drop structures" due to gravity influence. The ball \& pillow pattern strikingly mirrors modern-day, oval-shaped burrows with connected vertical, tubular-shaped conduits created by bioturbation such as marine worms. Also, note the ball \& pillow's isolated, oval-shaped structure lacking a vertical shaft which is similar to Figure 5. From French (2007). Reprinted with permission from Pearson (Publishing) 


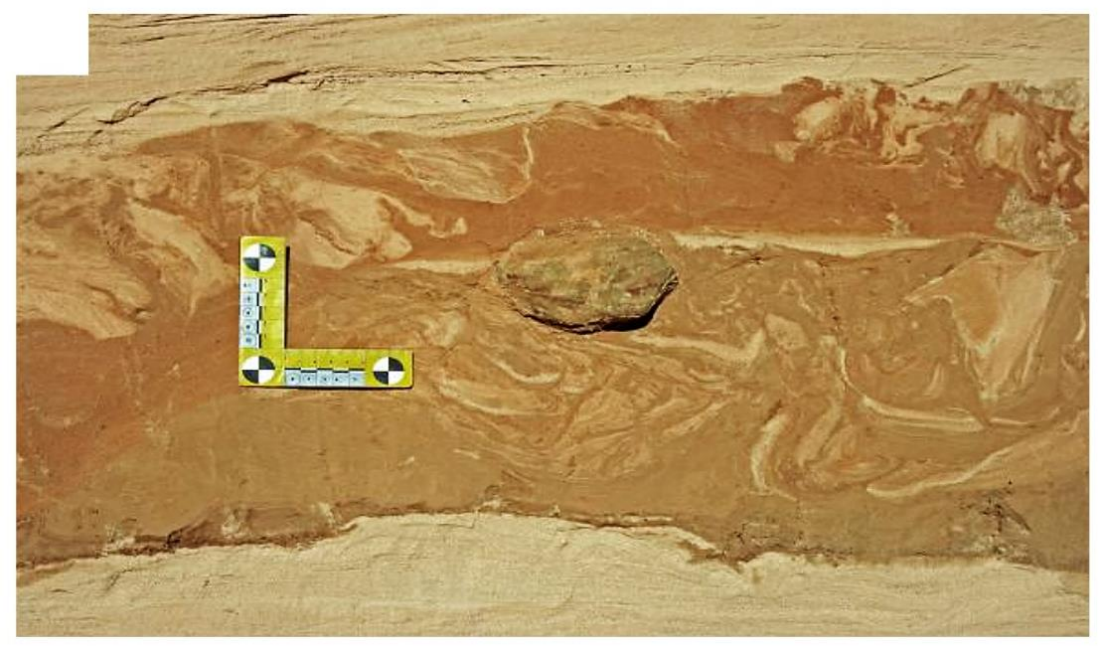

Figure 8. Field photo of a dark-colored, cryoturbated, marginal, glacio-lacustrine sediment composed of lenticular-shaped and irregular-shaped structures of silt and silty sand interlayered between upper and lower light-colored beds of sand, exposed in a quarry in Kraslava, Latvia. This is comparable to the supposed, bioturbation structures in Figures 5 and 6 because some authentic, burrowed sediments found in other sediment-cores have contrasting-colors due to the tunneled host-sediment displaying infilling-sediment composed of a different clast size vs. the clast-size of the surrounding host-sediment (Gingras et al., 2014), though oxygenation of some burrowed substrates can account for the color differentiation. A glacial dropstone is buried within the sediment reflecting a glacio-rafted origin for it. The dropstone, by the way, in this photo is generally only relative to the glacial dropstone found in east-central Kentucky, discussed in the text. From Zelcs et al. (2014). Permission to duplicate photo is granted by the editor and author of his publication, Vitalijs Zelcs, University of Latvia

$\&$ pillow structures in Figure 7 remarkably resemble actual, bioturbated burrows because of some of the structures having a narrow, vertical shaft connecting to an oval-shaped cavity that is later refilled with sediment. Finally, the author of the current study has seen an adequate amount of photographs of authentic, fossilized Chondrites and Planolites in rock. These structures are visually described as profuse patterns of adjoined, criss-crossing, vertical, diagonal and horizontal, wavy, bioturbated lineations that reflect ancient tunneling by the curvy, morphological shapes of extinct worms which are rather (though admittedly, not distinctly) unlike the supposed and similar-looking Chondrites' and Planolites' (pseudo)burrowed structures discussed in the study.

\subsection{Chondrites and Planolites in the Upper Devonian, New Albany Shale of East-Central Kentucky, USA}

An important contrast can be made between paleo-bioturbation structures such as Chondrites and Planolites in the time-equivalent, black shales in the Upper Devonian, New Albany Shale of east-central Kentucky, USA. (Jordan, $1985)$ to what is reported here in the current study. Jordan (1985, Table 1) specifically categorized all of the shales in his own study area according to two types: some shales that formed in a variably, oxygenated paleo-zone intermixed with a poorly, oxygenated paleo-zone; while the other shales formed in a completely, non-oxygenated paleo-zone but with no Chondrites nor Planolites in the latter paleo-zone. Thus, no Chondrites and Planolites in the black shale of the New Albany Shale reinforces the current study's sub-theme of the Chattanooga Shale Formation's black shale containing only cryoturbation structures but not bioturbation structures burrowed by paleo-worms.

\section{Evidence of an Upper Devonian, Cold Climate That Implies at Least Paleo-Seasonal Freezing, If not Paleo-Permafrost Conditions}

The study gathered evidence of an Upper Devonian, cold climate implying at least seasonal freezing (if not permafrost) of the paleo-seafloor in the paleo-Chattanooga Sea where the black shales developed. But first, we have to prove an upfreezing process that is capable of operating within modern, very high-latitude, seafloors since the literature relates the subjection of the upfreezing factor to only terrestrial environments. The terrestrial environment lends an appreciable big clue relative to the marine environment because the greatest control acting on upfreezing in terrestrial environments is groundwater (or pore water) due to the greatest amount of frost heave always occurring in wet localities (Washburn, 1969; Godzik \& French, 2004). Thus, this supports NRC's (1982, p. 14) report about seasonal freezing of the seabed in high-latitude seafloors even though sea ice is not even in contact with the seabed along different locations of the continental shelf in the Arctic Ocean such as Prudhoe Bay and 
Harrison Bay at northern Alaska, USA. Also, annual, subsea permafrost is recorded at other locations of the Arctic Ocean (NRC , 1982, p. 14; Harris et al., 2018, fig. 1.29). To conclude, upfreezing of both coarse clasts and objects within today's frozen, fine-grained seabeds is a substantial liklihood.

Relevant to the above, the Upper Devonian's (382.7 - 358.9 MYA) (Cohen et al., 2013) paleo-climate is traditionally considered as mostly warm but without any regard to if whether or not winters lowered temperatures enough for seasonal freezing (if not permafrost) to occur during this particular time span (Copper, 2002; Joachimski et al., 2009). But then investigators advanced the idea of very cold conditions occurring during the Frasnian Stage (Upper Devonian Period) (Issacsson et al., 2008) that extended into the Famennian Stage (Upper Devonian Period) with evidence of glaciation in landmasses located relatively adjacent to the paleo-Chattanooga Sea (Isbell et al., 2003; Caputo et al., 2008). Even more importantly, there are also very significant lines of evidence that clearly imply either permafrost or at least, seasonal freezing were situated close to the paleo-Chattanooga Sea of the structural Appalachian Basin during the Upper Devonian. Investigators have substantiated paleo-glaciation at the Upper Devonian limit (end-Famennian Stage) that occurs relatively proximal to the vicinity of the paleo-Chattanooga Sea, specifically, east-central Kentucky, USA (Lierman et al., 2015; Ettensohn et al. 2015), and distally north in West Virginia, western Maryland and central Pennsylvania, USA (Brezinski et al., 2009, p. 316). This is while authorities such as McGhee (2014) also argued for the presence of glaciers even earlier in time during the Upper Devonian's Frasnian Stage. The preceding, glaciated locations that infer paleo-permafrost, or at the least, paleo-seasonal freezing within the current study area will be appropriately elaborated upon later in the study.

\section{Application of the Upfreezing Effects Upon Specifics of the Paleontological Record}

The study was piqued initially when it noticed Conant \& Swanson's (1961, p. 56) astute observation that reported more fossils being anomalously found in the black shales versus the number found in the light-colored shales of the Chattanooga Shale Fm. This aroused suspicion within the current study which hints at some sort of sedimentological mechanism being responsible for the anomaly since a biological mechanism can be ruled out, as previously discussed. That generalized presumption then led to the current study recognizing an additional anomaly within a specific, stratigraphic column of the Chattanooga Shale Fm. containing a string of many conodont-elements relative to their apparent origination within a black shale (Figs. 2 and 3) whose pre-lithified, black shale paleoenvironment counteracted against the sustainment of ancient, marine macroorganisms, as previously discussed. This can now be meticulously manifested by using an example that is now presented here.

\subsection{Stratigraphic Column of the Chattanooga Shale Formation With Its Conodont-Elements}

The Chattanooga Shale Formation both underlies and crops out of the subsurface over much of the eastern half of the USA (Schieber, 2006) (Fig. 9). Focus is on the paleontology and general stratigraphy of a local outcrop (road exposure) physically located in central Tennessee (TN), USA (Fig. 9) while the pre-lithified form of the discussed, black shale was deposited in the pre-existing Chattanooga Sea within the structural Appalachian Basin. Over (2007, fig. 9) (Fig. 3) provides the very generalized, stratigraphic column of the Chattanooga Shale Formation that envelopes conodont-elements within an outcrop in the vicinity of Chestnut Mound, Smith County, in central Tennessee. A better look in detail, at the particular bedrock units in the same stratigraphic column but without any indication of the conodont-elements that were designated in Over (2007, fig. 9), is shown in Li \& Schieber (2015, fig. 2) (Fig. 2). At the $2 \mathrm{~m}$ depth mark of both Figures 2 and 3 in the current study, is a very thick layer (bed) of laminated black shale containing a string of the four following, specific four conodont-elements: I. (Icriodus) sp.; Ag. (Ancyrognathus calvini?); Pa. (Palmatolepsis winchelli?); and Ad. (Ancyrodella) sp. The above, specified conodont-elements were not indicated as molds by Over (2007), which favorably means that we are dealing with only conodont-elements capable of mobilizing upward when the fine-grained, black shale was pre-lithified. In general, according to the face value of any stratigraphic column, most paleontologists would typically assign an age to those four, different, conodont-elements conformable to the same age of the stratigraphic level in which they are found. But now we must factor in the previously-discussed situation of a significant thickness of black shale encasing those conodont-elements $(\sim .2 \mathrm{~m}$ thick in this case, found between the $1.85 \mathrm{~m}$ and 2.05 depth mark of Figure 2), which is, as previously discussed, indicative of a very long residence time of accumulating paleo-black sediment that chemically heightened the lower, anaerobic marine layer up to virtually the very top of the paleo-water column. Also, the $\sim .2 \mathrm{~m}$ thick black shale would have been significantly greater in thickness during 




Figure 9. Diagram of the present-day, eastern-half of mainland USA showing subsurface and outcropping Upper Devonian, black shales that formed in structural basins. The age-equivalent, other black shale formations other than the Chattanooga Shale in the Appalachian Basin are: the New Albany Shale in the Illinois Basin; and the Antrim Shale in the Michigan Basin (which is not discussed). A composite of the stratigraphic sections (Figs. 2 and 3 ) is geo-physically located within the small, irregular-shaped, purple-colored, perimeter-lines that are sketched within the state of Tennessee (TN), USA. From Schieber (2006). Permission to duplicate figure, courtesy of Juergen Schieber

its pre-lithification because of precompaction. Thus, this situation eliminates the possibility of the previously-mentioned, specific, conodont-animals existing in the anaerobic paleo-water zone which means their conodont-elements must have originated lower down the stratigraphic column where there are underlying units of greenish-gray mudstones alternating with very thin black shales that begin at approx. the $1.8 \mathrm{~m}$ depth mark in Figures 2 and 3. This is because light-colored mudstones represent at least a dysoxic to oxic paleo-water column above the paleo-seafloor.

It should be noted here, that the type of black shale being preliminarily investigated for paleo-upfreezing must strictly conform to an anaerobic paleo-environment simply because not all black shales reflect an anaerobic paleo-environment. For example, pyritized, black shale when formed together in conjunction with Tasminite cysts and iron, had caused the overlying paleo-water column to be oxygenated above these particular, pre-lithified black shales (Brett \& Allison, 1998). This of course, would contradict an existence of an anaerobic paleo-water zone which is the case in Figure 2 since it shows pyritized, black shale at the same level ( $6.8 \mathrm{~m}$ depth mark) as the following conodont-elements in Fig. 3: Pa. gracilis sigmoidalis; Pa. marginerfera marginifera; Po. communis communis; and Bi. arculeatus arculeatus. Thus, we cannot rule out the preceding conodont-animals from existing above a paleo-seafloor composed of very thick, black, dead organic sediment, which was pyritized in this very case. The above scrutiny also applies to other stratigraphic sections of Over (2007, fig. 5), for example: within his study area in Hurricane Bridge, DeKalb County, TN, there are many numerous, different conodont-elements found either at the same level or at different levels within the general black shale unit that falls within the L-Um marginera Conodont Zone. However, since Over's (2007, fig. 5) study area unluckily lacks a correlative, detailed stratigraphic-section (such as Figure 2 of the current study), then no implication of any stratigraphic dislocations / displacements can be made. This is because the possibility exists of either: both thin and thick, light-colored shale beds being found interspersed within the much bigger, black shale unit; or the black shale unit may be pyritized which could reflect an oxygenated, paleo-water zone above a paleo-environment of dead organic, black sediment (Brett \& Allen, 1998), as previously discussed.

\section{Relationship to the Upper Devonian's Frasnian and Fammenian Stages -Global Extinctions}

A reasonable correlation of a very, cold paleo-climate has been made to both the Frasnian and Famennian stages of the Upper Devonian, having an association with a mass extinction of many macro-species that occurred during the 
Kellwasser Event, 376 - 375 MYA (McGhee, 2014) and during the Hangenberg Event, 358.9 MYA (Kaiser, 2005; Lakin et al., 2016), respectively. In the meantime, the current study underscores a valid hypothesis of either paleo-permafrost or at the least, seasonal paleo-freezing being correlative to marine paleo-environments not conducive to sustaining life forms any bigger than microbes during those same timeframes. Supportive of that, is the previously-mentioned, glacial evidence (Section 5 of this study) existing in the form of confirmed, glacigenic, terrestrial, sediment deposition (diamictites) which is found in the paleo-east (West Virginia, Maryland and Pennsylvania, USA) during the end of the Famennian Stage. That also marks the temporary termination of marine black shale deposition, located in the paleo-north (Ohio, USA) (Brezinski et al., 2010). Also, an existing, very large, heavy, igneous, glacial "dropstone" (originated from glacial ice-rafting) was found correlatively embedded and consolidated within black shale of the Upper Devonian, Cleveland Member (of the Ohio Shale) located proximally, in Kentucky, USA (Lierman et al., 2015; Ettensohn et al., 2015). In addition, closer to the geologic time of where the questionable, stratigraphic level of the conodont-element clasts discussed and pointed out in the current study (which was during the Upper Devonian Frasnian Stage) (Figs. 2 and 3), McGhee (2014) argued for the presence of glaciers during the same timeframe while he justifiably added that the glacial evidence was erased by subsequent, later glacial bulldozing, during the previously-mentioned, Famennian Stage. In support of that, McGhee (2014) cited many papers authored by other people within the peer-reviewed literature about the occurrence of glaciers during that same time interval.

All together, we then should correlate the study area's key, thick, black, shale units to either coincidental, paleo-glacial times or to the paleo-cold environmental conditions promulgated by the current study. Thus, it is suggested here that paleo-subsea permafrost was the most likely environmental condition there in the paleo-Chattanooga Sea during the Upper Devonian which explains the absence of conodont-animals juxtaposed and complemented by the discussed, anaerobic, paleo-sea realm. This is in agreement with McGhee (2013, fig. 4.3 and p. 129) and De Vleeschouwer et al. (2013, fig. 6) who reported anoxia and very cold temperatures coincidently occurring together during the Upper Devonian Period's end-Frasnian Stage, and rhythmitic parts of the Famennian Stage within the continent of Laurasia (specifically in Poland), respectively. When we factor in the paleo-upfreezing process that operated within the pre-lithified, black shale paleoenvironments, it accounts for why the only fish found today in very cold, harsh seas underlain by permafrost (versus conodont-animals and their elements never found in bedrock indicative of very cold, harsh, marine paleo-environments) are ones which possess the property of anti-freeze proteins in their bodies (Hanchet et al., 2015). Thus, a generalized, extreme, climate change from warm to cold (whether gradual or relatively fast) conditions is chosen as the agent by the current study that caused both the Frasnian and Famennian mass extinctions while aftermath-survivors (such as conodont-animals and some other fish) were conspicuously successful at finding refugia in more hospitable paleo-environments during those times of extinction. For example, hospitable, Upper Devonian paleoenvironments during that same timeframe would have been any warmer, isolated, very big and small pockets of marine areas surrounded by cold-temperature waters.

\section{The Correlation and Resemblance of Anoxia Occupying the Entire Water Column to Other Upper Devonian, Pre-lithified, Black Shale Environments}

The study's thesis would be incomplete if we did not offer current evidence from two schools of thought concerning a descrepency about if whether or not anoxia can exist within an entire water column in either today's world or during the Upper Devonian world. NOAA (2018) reports that general wave action induces mixing while photosynthesis replenishes lost oxygen in the upper layer due to oxygen removal both by the respiration of organisms and when organic matter is biochemically degraded. But that equation is interestingly tempered or counterbalanced by Leeder (2011) who reports about anoxism existing in the entire water column of the eastern Mediterranean Sea as evidenced by the presence of sulfur-utilizing bacteria which require dependency on the photic zone in hydrogen-sulfide rich waters. We can strongly correlate the current, marine condition together with the Upper Devonian's paleo-marine condition by embracing Sinninghe-Damste \& Schouten's (2006) conclusion of anoxia occupying the entire paleo-water column within two, separate, Upper Devonian, black shale units that are very distant from one another, located in Alberta, Canada and in Poland based on their fossilized, carotenoid-derivatives analysis of these Upper Devonian, black shales. Their particular conclusion about full-scale, anoxia surrounding pre-lithified, black shales can be vigorously correlated to a study by Knapp (2016) concerning the Upper Devonian, Duvernay Formation in Alberta, Canada which is coincidently time-equivalent to the previously-discussed, black shales of the current study, namely, the Chattanooga, Ohio and New Albany formations (Knapp, 2016, p. 2). Its paleo-structural, deep intra-cratonic basin (the Western Canada Sedimentary Basin) accumulated pre-lithified, black mudstone that consequently heightened anoxia up to the sea surface according to Sinninghe-Damste \& Schouten (2006) as previously mentioned. This means that anoxia there had to 
rise up through great depths of seawater. Depths there were $\geq 53 \mathrm{~m}$ (Knapp, 2016), while in contrast to that, anoxia within the pre-existing Chattanooga Sea would have had to progress upward through only $<30 \mathrm{~m}$ of seawater depth to reach the sea surface while within a shelf setting, as discussed in Section 4.1 of the study. Thus, when we combine the residence-time of the thick, pre-lithified black shale factor with the shallow-depth paleo-sea factor, it points to anoxia heightened up to virtually the topmost, stratified layer of the paleo-water column in the paleo-Chattanooga Sea.

Patterns in the black mudstone of the Duvernay Formation resemble the same pattern of paleo-anoxic and paleo-cold temperature indicators as in the pattern of features discussed in the current study. For instance, Knapp's (2016, fig. $2.3 \mathrm{~F}$ ) photo of supposed bioturbation-structures in black mudstone features the same, small, sparse, isolated, lenticular-shaped ovals as in Figures 5 and 6 of the current study. Those structures lack the horizontal and vertical, criss-crossing, tunneled lineations that we would typically expect to see in authentic Chondrite and Planolite bioturbation structures, and thus, they are deemed here only as cryogenic structures. Another indicator is a description of a bottom-section in facies sample, SCL Kaybob 02-22 \#17 3080.40m that revealed laminated black mudstone (Knapp 2016, Fig. 2.3) containing a small amount of conodont-elements (Knapp, 2016, pp. 130 131). These conodont-elements had to have been paleo-displaced (through upfreezing) from a feasible, stratigraphically-lower, pre-lithified bedrock that at one time sustained those particular conodont-animals since proven anoxia of the entire paleo-water column within their paleoenvironment of pre-lithified, black shale according to Sinninghe-Damste \& Shouten (2006) would have prevented them from pre-existing there while they were ultimately fossilized in the bedrock in which they are now found in. In that same case, those conodont-elements were most likely displaced from the paleo-surface of an upper section in a lower bed of wackestone (SCL Kaybob 02-22 \#19 3082.50m) when carbonate deposition ceased while black muddy sediment began accumulating upon the conodont-elements (Knapp, 2016, pp. 130 - 131).

\section{Supersession of a Full-Scale, Anoxic Paleo-Water Column by Seawater Freezing}

The preponderance of the evidence favoring anoxism of the entire paleo-water column within the paleo-Chattanooga Sea negates just simple speculation about it, although only testing of it using investigative techniques such as the ones employed by Sinninghe-Damste \& Shouten (2006) would verify it as factual. But, just in case if anoxism of the entire water column was not the primary reason for keeping conodonts outside of the previously-discussed paleoenvironment containing pre-lithified, black shale, then we may point to the previously-discussed harsh, cold conditions during the Upper Devonian Period as the primary reason which then easily supersedes in this matter.

\section{Conclusions}

The study takes an alternative look at original interpretation and apperception made in the established literature regarding the actual age of fossilized conodont-elements in their surrounding host-rock (black shale). A reassessment is introduced here justifiably proclaiming the upfreezing factor and its effects upon coarse, fossilized, apatite-composed, conodont-elements within pre-lithified, black shale, while also noting how the upfreezing factor could blunder age-determinations made by paleontologists / stratigraphers. Thus, the study elevates their acumen towards making a better or veritable reading of the paleontological / stratigraphical record relative to particular, conodont-elements such as the ones discussed here, even though their age may not match up to the same age as the surrounding host-rock, especially in particular types of black shales. For instance, if an apatite-composed, conodont-element in a particular black shale bed is deemed as most likely originating from a stratigraphically, lower, light-colored, shale bed because of the paleo-upfreezing factor, then the broad age-determination of the conodont-element fossil should be $\geq$ in age to the surrounding, host-rock. The thesis of the current study also synomynously demystifies Conant \& Swanson's (1961) puzzling observation of anomalously finding more fossils in the black shales versus the number found in the light-colored shales of the Chattanooga Shale Fm. This is done by simply subjecting those fossils to the same criteria offered in the current study.

The insight brought about in this study also lends a good hint to the agent that caused two separate extinctions of many species during the Frasnian and Famennian stages of the Upper Devonian Period which is determined here to be due to paleo-permafrost, subsea conditions, and / or anoxia occupying the entire paleo-water column.

\section{Acknowledgements}

Many thanks to Carlton Brett for communicating a lot of needed, background information. Gratitude is extended to an anonymous reviewer chosen by the Earth Science Research Journal who provided constructive and insightful suggestions / comments that proved useful to the manuscript. Juergen Schieber imparted sportsman-like, encouragement towards a reinterpretation of a particular, stratigraphic aspect relevant to his own published work, for which the author is appreciative. David De Vleeschouwer and George McGhee gave helpful, clarifying 
information. Jeffrey Over supplied some background information.

\section{References}

Barron, L. S., \& Ettensohn, F. R. (1981). Paleoecology of the Devonian - Mississippian black-shale sequence in eastern Kentucky with an atlas of some common fossils. U.S. Department of Energy, Eastern Gas Shales Project, Contract No. DE-AC21-76ET12040. https://doi.org/10.2172/6459347

Brett, C. E., \& Allison, P. A. (1998). Paleontogical approaches to the environmental interpretation of mudrocks. In J. Schieber et al. (eds.), Mudstones and Shales, Vol. 1. Basin Studies, Sedimentology and Paleontology. Stuttgart, Schweizerbartsche Verlagsbuchhandlung, 301-349.

Brezinski, D. K., Cecil, C. B., \& Skema, V. W. (2010). Late Devonian glacigenic and associated facies from the central Appalachian Basin, eastern United States. Geological Society of America Bulletin, 122(1/2), 265-281. https://doi.org/10.1130/B26556.1

Brezinski, D. K., Cecil, C. B., Skema, V. W., \& Kertis, C. A. (2009). Evidence for long-term climate change in Upper Devonian strata of the central Appalachians. Paeleogeography, Paeleoclimatology, Paeleoecology, 294, 315-325. https://doi.org/10.1016/j.palaeo.2009.10.010

Caputo, M. V., de Melo, J. H. G., Streel, M., \& Isbell, J. L. (2008). Late Devonian and Early Carboniferous glacial records of South America. In C.R. Fielding, T.D. Frank, \& J.L. Isbell (eds.), Resolving the Late Paleozoic Ice Age in Time and Space. Geological Society of America Special Publication, 161-173. https://doi.org/10.1130/2008.2441(11)

Cohen, K. M., Finney, S. C., Gibbard, P. L., \& Fan, J.-X. (2013). The ICS (International Commision on Stratigraphy) International Chronostratigraphic Chart. Episodes, 36, 199-204.

Conant, L. C., \& Swanson, V. E. (1961). Chattanooga Shale and related rocks of central Tenneessee and nearby areas. Geol. Survey Professional Paper 357, U.S. Geological Survey, Washington. https://doi.org/10.3133/pp357

Copper, P. (2002). Silurian and Devonian reefs: 80 million years of global greenhouse between two ice ages. SEPM Spec. Publ. 72, 181-238. https://doi.org/10.2110/pec.02.72.0181

De Vleeschouwer, D., Rakocinski, M., Racki, G., Bond, D. P. G., Sobien, K., \& Claeys, P. (2013). The astronomical rhythm of Late-Devonian climate change (Kowala section, Holy Cross Mountains, Poland). Earth, Planet. Sci. Lett., 365, 25 - 37. http://dx.doi.org/10.1016/j.epsl.2013.01.016

Diaz, J., \& Rosenberg, R. (2008). Spreading dead zones and consequences for marine ecosystems. Science, v. 321, 926. https://doi.org/10.1126/science.1156401

Ettensohn, F. R., Lierman, R. T., Mason, C. E., Dennis, A. J., \& Anderson, E. D. (2015). Kentucky dropstone "ices" the case for Late Devonian, Alpine Glaciation in central Appalachians: implications for Appalachian tectonics and black shale. In,F.R. Ettensohn et al. (eds.), Silurian, Devonian, and Mississippian Hydrocarbon-Rich Horizons in Northeastern Kentucky: Perspective in the Field (pp. 56 - 66), American Institute of Professional Geologists (Kentucky Section) Field Trip.

French, H. (2007). The Periglacial Environment. J. Wiley \& Sons, Inc., UK: many locations. https://doi.org/10.1002/9781118684931

Gingras, M. K., Pemberton, S. G., \& Smith, M. (2014). Bioturbation; reworking sediment for better or worse. Oilfield Review, 26(4), 46-58.

Godzik, J. S., \& French, H. (2004). Apparent upfreezing of stones in Late-Pleistocene coversand, Belchatow vicinity, Poland. Permafrost and Periglacial Proc., 15, 359-366. https://doi.org/10.1002/ppp.491

Hanchet, S., Dunn, A., Parker, S., Horn, P., Stevens, D., \& Mormede, S. (2015). The Antarctic toothfish (Dissocticus mawsoni): biology, ecology and life history in the Ross Sea region. Hydrobiologia, 761, 397-414. https://doi.org/10.1007/s10750-015-2435-6

Harris, S. A., Brouckov, A., \& Guodong, C. (2018). Geocrology: Characteristics and Use of Frozen Ground and Permafrost Landforms. CRC Press: many locations. https://doi.org/10.4324/9781315166988

Iannicelli, M. (2017). Solving the mystery of endless life between conodonts and lampreys, plus a reason for final extinction of the conodonts. Journal of Oceanography and Marine Research, S (Special Issue) 1: 001.

Iannicelli, M. (2018). Explaining the crude and simple mechanics of parasitic feeding by conodonts. Journal of Oceanography and Marine Research, 6, 177. https://doi.org/10.4172/2572-3103.S1-001 
Isaacson, P. E., Diaz-Martinez, E., Grader, G. W., Kalvoda, J., Babek, O., \& Devuyst, F. X. (2008). Late Devonian-earliest Mississippian glaciation in Gondwanaland and its biogeographic consequences. Palaeogeogr. Palaeoclimatol. Palaeoecol. 268(3-4), 126-142. https://doi.org/10.1016/j.palaeo.2008.03.047

Isbell, J. L., Miller, M. F., Wolfe, K. L., \& Lenaker, P. A. (2003). Timing of late Paleozoic glaciations in Gondwana: was glaciation responsible for the development of Northern Hemisphere cyclothems? Geological Society of America, 370, 5-24. https://doi.org/10.1130/0-8137-2370-1.5

Joachimski, M. M., Breisig, S., Buggisch, W., Talent, J. A., Mawson, R., Gereke, M., \& Morrow, J. R. (2009). Devonian climate and reef evolution: insights from oxygen isotopes in apatite. Earth Planet. Sci. Lett. 284(3-4), 599-609. https://doi.org/10.1016/j.epsl.2009.05.028

Jordan, D. W. (1985). Trace fossils and depositional environments of Upper Devonian black shales in east-central Kentucky, USA. In, H.A. Curran (ed.), Biogenic Structures: Their Use in Interpreting Depositional Environments, (pp. 279 - 298). SEPM (Society for Sedimentary Geology), Special Publication, v. 35. https://doi.org/10.2110/pec.85.35.0279

Kaiser, S. I. (2005). Mass extinctions, climatic and oceanographic changes at the Devonian / Carboniferous boundary. Ph.D. Thesis: Ruhr - Universitat Bochum, Germany.

Lakin, J. A., Marshall, J. G. A., Troth, I., \& Harding, I. C. (2016). Greenhouse to icehouse: a biostratigraphic review of latest Devonian-Mississippian glaciations and their global effects. Geological Society of London, Special Pub, 423(1). 439-464. https://doi.org/10.1144/SP423.12

Leeder, M. R. (2011). Sedimentology and Sedimentary Basins: from Turbulence to Tectonics. J. Wiley \& Sons, Inc., Chichester, UK.

Li, Y., \& Schieber, J. (2015). On the origin of a phosphate enriched interval in the Chattanooga Shale (Upper Devonian) of Tennessee-A combined sedimentologic, petrographic, and geochemical study. Sedimentary Geology, 329, 40-61. https://doi.org/10.1016/j.sedgeo.2015.09.005

Lierman, R. T., Mason, C. E., \& Ettensohn, F. R. (2015). Granitic dropstone embedded in the uppermost Cleveland Member of the Ohio Shale. In, F.R. Ettensohn et al. (eds.), Silurian, Devonian Mississippian, Hydrocarbon-rich Horizons in northeastern Kentucky: Perspectives in the Field (pp. 56 - 66). American Institute of Professional Geologists (Kentucky Section) Field Trip.

McGhee, G. R. (2013). When the Invasion of Land Failed: the Legacy of the Devonian Extinctions. Columbia Univ. Press: N.Y. and Chichester, 317 pp. https://doi.org/10.7312/columbia/9780231160575.001.0001

McGhee, G.R. (2014). The Late Devonian (Frasnian / Fammenian) mass extinction: a proposed test of a glacial hypothesis. Geological Quarterly, 58(2), 263-268. https://doi.org/10.7306/gq.1143

Melnikov, V. P., \& Spesivtsev, V. I. (2000). Cryogenic Formations in the Earth's Lithosphere. Novosibirsk: Scientific Pub. Center of the UIGGM, Siberian Branch of the RAS. [English and Russian Trans.], 343 pp.

NOAA (National Oceanic and Atmospheric Administration). Retrieved from https://oceanservice.noaa.gov/education/kits/estuaries/media/supp_estuar10d_disolvedox.html. [cited: 21 December, 2018].

NRC (National Research Council) (U.S.) (1982). Understanding the Arctic Seafloor for Engineering Purposes. Committee on Arctic Seafloor Engineering, U.S. Dept. of Commerce, Nat. Tech. Info. Svc.

Over, D. J. (1990). Conodont Biostratigraphy of the Woodford Shale (Late Devonian - Early Carboniferous) in the Arbuckle Mountains, South - Central Oklahoma. Ph.D. Thesis, Texas Tech University, Texas, USA.

Over, D. J. (2007). Biostratigraphy of the Chattanooga Shale, Middle and Upper Devonian, Southern Appalachian Basin, eastern United States. Journal of Paleontology, 81(6), 1194-1217. https://doi.org/10.1666/06-056R.1

Prothero, D. R. (2013). Bringing fossils to life. Columbia University Press: NY and the UK, $3^{\text {rd }}$ ed.

Schatzl, R. J., \& Thompson, M. L. (2015). Soils: Genesis and Geomorphology. Cambridge University Press: NY, NY, USA.

Schieber, J. (1994). Evidence for high-water events and shallow-water deposition in the Chattanooga Shale, Devonian, central Tennessee, USA. Sedimentary Geology, 93(3 and 4), 193-208. https://doi.org/10.1016/0037-0738(94)90005-1

Schieber, J. (2003a). Black shales. In, G.V. Middleton et al. (eds.), Encyclopedia of Sediments and Sedimentary 
Rocks (pp. 83 - 85). Kluwer Scientific Publishers-Springer, Berlin.

Schieber, J. (2003b). Simple gifts and buried treasures - implications of finding bioturbation and erosion surfaces in black shales. The Sedimentary Record, 1(2), 4-8. https://doi.org/10.2110/sedred.2003.2.4

Schieber, J. (2006). Devonian black shales, eastern U.S.A.: Chattanooga, New Albany and Ohio shales. Retrieved from [http://www.shale-mudstone-research-schieber.indiana.edu/devonian-black-shales.htm]. Indiana University, Dept. of Geosciences (Bloomington, IN, USA), [Cited: 23 October, 2018].

Tyson, R. V., \& Pearson, T. H. (1991). Modern and ancient continental shelf anoxia: a review. In, R.V. Tyson \& T.H. Pearson (eds.), Modern and Ancient Continental Shelf Anoxia (pp. 1 - 24). Geological Society of America, Special Publication 58. https://doi.org/10.1144/GSL.SP.1991.058.01.01

Washburn, A. L. (1969). Weathering, frost action, and patterned ground in the Mesters Vig District, north-east Greenland. Meddelelser om Gronland, 176.

Zelcs, V., Soms, J., \& Grieskalns, E. (2014). Kame terrace in the Upper Daugava depression at Rakuti near Kraslava (Stop 10). In, V. Zelcs \& M. Nartiss (eds.), Late Quaternary Sediments and History from Glacial to Postglacial Environments, (pp. 61 - 66). Latvian Association for Quaternary Research. Excursion Guide, August 16 - 22, 2014, University of Latvia. https://doi.org/10.22364/lqtpsh.2014.10

\section{Copyrights}

Copyright for this article is retained by the author(s), with first publication rights granted to the journal.

This is an open-access article distributed under the terms and conditions of the Creative Commons Attribution license (http://creativecommons.org/licenses/by/4.0/). 